\title{
MicroRNAs as Targets and Tools in B-Cell Lymphoma Therapy
}

\author{
Kalman Szenthe ${ }^{1}$, Katalin Nagy ${ }^{2}$, Krisztina Buzas ${ }^{3,4}$, Hans Helmut Niller ${ }^{5}$, Janos Minarovits ${ }^{3 *}$ \\ ${ }^{1}$ RT-Europe Nonprofit Research Center, Mosonmagyarovar, Hungary; ${ }^{2}$ Department of Oral Surgery, Faculty of Dentistry, University \\ of Szeged, Szeged, Hungary; ${ }^{3}$ Department of Oral Biology and Experimental Dental Research, Faculty of Dentistry, University of \\ Szeged, Szeged, Hungary; ${ }^{4}$ Institute of Biochemistry, Biological Research Center of the Hungarian Academy of Sciences, Szeged, \\ Hungary; ${ }^{5}$ Department of Medical Microbiology and Hygiene, University of Regensburg, Regensburg, Germany. \\ Email: ${ }^{*}$ minimicrobi@hotmail.com
}

Received January $23^{\text {rd }}, 2013$; revised February $25^{\text {th }}, 2013$; accepted March $5^{\text {th }}, 2013$

\begin{abstract}
MicroRNAs (miRNAs) are posttranscriptional regulators fine-tuning the level of most messenger RNAs (mRNAs) and proteins in mammalian cells. Their expression is dysregulated in neoplastic cells and upregulated or downregulated miRNAs play an important role in tumorigenesis. Changes in the miRNA transcriptome appear to be suitable markers for the differential diagnosis of various B-cell lymphoma types and there are therapeutic attempts to normalize the expression level of key cellular miRNAs involved in lymphomagenesis. In this review we wish to outline the most recent developments in the application of sophisticated, chemically modified antisense oligonucleotides and their nanoparticle complexes to suppress oncogenic miRNAs. These advances form the basis of a new therapeutic approach that may complement current protocols for B-cell lymphoma therapy. Anti-cytokine therapy aiming at the removal of cytokines that activate key oncomirs, and switching on silenced tumor suppressor miRNAs by epigenetic drugs might also be considered, on the long run, in the treatment of well defined B-cell lymphoma types.
\end{abstract}

Keywords: MicroRNAs; B-Cell Lymphoma Therapy; Antisense Oligonucleotides; Anti-Cytokine Therapy; Epigenetic Drugs

\section{Introduction}

Recently, microRNAs (miRNAs) emerged as a new class of regulators of a wide variety of physiological processes [1]. miRNAs usually downregulate messenger RNA (mRNA) levels and protein levels by binding to complementary regions on their target mRNAs. miRNA-mRNA association may either facilitate mRNA breakdown or block mRNA translation.

Dysregulated expression of certain miRNAs plays a role in the development of malignant neoplasms [2-4]. Increased level of several miRNAs, called oncomirs, facilitates oncogenesis and tumor progression. Other miRNAs act similarly to the products of tumor suppressor genes: their reduced expression may result in uncontrolled cell proliferation and altered cellular behaviour.

\section{2. miRNAs as Pleiotropic Posttranscriptional Regulators in Normal and Neoplastic Cells}

\subsection{Biogenesis of MicroRNAs}

miRNAs are transcribed in most cases by RNA poly-

"Corresponding author. merase II (Pol II) from independent transcription units or they are processed from introns of transcripts (for review see $[1,3])$. Typically the primary Pol II product (primiRNA) is processed in the nucleus by the RNase III Drosha resulting in a stem and loop structure called premiRNA. The approximatively 70 nucleotide long premiRNA molecule is carried to the cytoplasm by Exportin 5, a nuclear export protein. As a next processing step, DICER1, a cytoplasmic RNAse III enzyme removes the loop of the pre-miRNA and the resulting double stranded RNA is loaded onto an Argonaute (Ago) protein, a component of the RNA-induced silencing complex (RISC). One strand of the approximately 22 nucleotide long duplex RNA represents the guide strand or mature miRNA that remains associated with Ago, whereas the other strand is degraded. As few as 6 nucleotides of the mature single stranded miRNA (nucleotides 2 - 7) form the "seed region" that plays a major role in selecting the 3 ' untranslated region ( 3 ' UTR) of the target mRNA. Because the seed region, where full complementarity is required with the target mRNA for RISC function, is short, a miRNA may potentially recognize multiple mRNA targets. It is also worthy to note, however, that the very 
same 3' UTR may bind more than one miRNA species (reviewed in [1,3]).

\subsection{Dysregulation of miRNA Expression in B-Cell Lymphomas}

The pattern of miRNA expression in neoplastic cells differs from the miRNA transcriptome (miRNAome) of their normal counterparts (for review see [3]). In addition, the expression signatures of miRNAs appear to be suitable markers for the differential diagnosis of various malignant tumors including the different B-cell lymphoma types [5]. Some of the differentially expressed miRNAs apparently play an important role in the initiation and maintenance of the malignant behaviour, which implies that overexpression or inhibition of key microRNAs may revert the malignant phenotype. The best characterized miRNAs most frequently upregulated or downregulated in the major B-cell lymphoma types are summarized in Tables 1 and 2 (for a comprehensive review see also [4]). Tables 1 and 2 also show their target mRNAs and putative role in lymphomagenesis. It is important to note that - depending on the cellular context - the very same miRNA may either facilitate or inhibit tumorigenesis. Thus, miR-155, a multifunctional regulator molecule upregulated in diffuse large B-cell lymphomas (DLBLs) and Hodgkin lymphomas acted as an oncomir in a transgenic mouse model, where its ectopic expression resulted in pre-B cell proliferation and lymphoblastic leukemia/ lymphoma [6-8]. All these changes were attributed to a release of the interleukin-6 (IL-6) pathway from its inhibitory control by miR-155 [9]. In gastric cancer cells, however, miR-155 was downregulated and its overexpression suppressed cell migration and invasion. Thus, in gastric cancer cells miR-155 acted as a tumor suppressor targeting SMAD2, a component of the transforming growth factor beta $(\mathrm{TGF} \beta)$ signalling pathway [10]. In addition, Babar et al. observed that although induction of high levels of miR-155 in a tetracycline-controlled knockin mouse model caused the development of disseminated pre-B cell lymphoma, highly elevated miR-155 expression in the brains of the same mice was insufficient to induce brain tumors [11].

\subsection{Attempts to Normalize the Expression of Key Cellular miRNAs in Various B-Cell Lymphoma Types}

As illustrated above, miR-155 has emerged as a pleiotropic regulator of numerous biological processes. Thus, it became a logical therapeutic goal to attenuate its oncogenic functions to complement, on the long run, current protocols for lymphoma treatment. High affinity binding of anti-miR oligonucleotides to distinct microRNAs may sequester their target without causing its de- gradation, whereas a lower-affinity binding promotes miRNA degradation [12]. Early in vivo attempts of sequence specific silencing by short hairpin RNAs failed due to the activation of the immune system, toxic offtarget effects, and saturation of the endogenous microRNA pathway (reviewed in $[13,14]$ ). However, more sophisticated, chemically modified antisense oligonucleotides including locked nucleic acid (LNA) oligonucleotides, peptide nucleic acids (PNAs) conjugated either to a cell-penetrating peptide or polylysine, and cholesterolconjugated RNAs called "antagomirs" proved to be effective inhibitors of microRNAs both in vitro and in vivo [14-18]. Fabani et al. reported that a peptide nucleic acid (PNA) oligonucleotide containing four D-lysine residues to ensure proteolytic stability and enhanced cellular uptake could inhibit miR-155 both in vitro and in the spleens of experimental mice receiving $50 \mathrm{mg} \mathrm{PNA} / \mathrm{kg} /$ day for 2 days [16].

To explore the advantages of the nanoparticle delivery systems that permit targeting of miRNA inhibitors to selected cells and tissues, anti-miR-nanoparticle complexes were constructed and tried successfully in clinically acceptable and therapeutically affordable doses in mice [11, $19,20]$. Babar et al. demonstrated that in spite of the potential difficulties of cellular internalization, antisense peptide nucleic acids encapsidated into biodegradable poly (lactic-co-glycolic acid) (PLGA) particles coated with penetratin inhibited miR-155 and decreased the growth rate of pre-B-cell tumors in a knock-in mouse model [11]. Although penetratin facilitates uptake into various cell types, it was observed that the systematically administered nanoparticles showed preferential targeting to tumor tissue.

miR-155 is indispensable for the development of an optimal $\mathrm{T}$ cell dependent antibody response and controls $\mathrm{T}$ helper cell differentiation by regulating cytokine production [21]. miR-155 expression leads to elevated tumor necrosis factor alpha (TNF $\alpha$ ) levels whereas TNF $\alpha$ induces miR-155 expression. In a subgroup of diffuse large $\mathrm{B}$ cell lymphoma, called activated $\mathrm{B}$ cell-like or nongerminal centre (ABC or non-GC) DLBC, augmented miR-155 expression was found due to an increased TNF $\alpha$ production. The high miR-155 level could be reduced in non-GC DLBC cell lines cultured in vitro by adding eternacept, a soluble TNF $\alpha$ receptor or infliximab, a neutralized humanized monoclonal antibody against $\mathrm{TNF} \alpha$, to the culture medium [22]. These observations indicate that anti-cytokine therapy could potentially be used to normalize the expression of miR-155, a cytokine-regulated microRNA, in a subset of patients with DLBC. Such a treatment may improve the prognosis and relapse-free survival of the $\mathrm{ABC} /$ non-GC group of DLBC. Reactivating silenced genes coding for miRNAs that inhibit cell proliferation similarly to tumor suppressor proteins appears to be a promising strategy in lymphoma 
Table 1. MicroRNAs upregulated in B-cell lymphomas.

\begin{tabular}{|c|c|c|}
\hline Lymphoma type & miRNA (references) & Comment \\
\hline \multirow{11}{*}{$\begin{array}{l}\text { Diffuse large B-cell } \\
\text { lymphoma (DLBCL) }\end{array}$} & miR-19b [35] & $\begin{array}{l}\text { component of the miR-17-92 cluster that promotes cell proliferation and } \\
\text { angiogenesis, represses apoptosis }\end{array}$ \\
\hline & $\operatorname{miR}-17-5 p[36]$ & component of the miR-17-92 cluster \\
\hline & miR-143 [37] & \multirow{2}{*}{$\begin{array}{l}\text { miR-145 or miR-143 play a tumor-suppressive role in various cancers; Ras } \\
\text { activation represses the miR-143/145 cluster }\end{array}$} \\
\hline & $\operatorname{miR}-145$ [37] & \\
\hline & $\operatorname{miR}-155[5,38]$ & oncomir, regulates proliferation, promotes to cell survival \\
\hline & $\operatorname{miR}-29 b[5,39]$ & regulates P53 \\
\hline & miR-146a [5] & $\begin{array}{l}\text { down-regulates TRAF6, IRAK1, the Toll-like and cytokine receptor pathway } \\
\text { adaptor molecules }\end{array}$ \\
\hline & $\operatorname{miR}-365[5]$ & direct negative regulator of IL-6 \\
\hline & $\operatorname{miR}-30 \mathrm{~b}[5,40]$ & blocks terminal B-cell differentiation \\
\hline & let-7f [5] & let-7 family member, tumor suppressor \\
\hline & $\operatorname{miR}-9[5]$ & activated by MYC/MYCN; regulates E-cadherin \\
\hline \multirow{9}{*}{$\begin{array}{l}\text { Chronic lymphocytic } \\
\text { leukemia/small lymphocytic } \\
\text { lymphoma (CLL/SLL) }\end{array}$} & $\operatorname{miR}-34 \mathrm{~b}[5]$ & tumor suppressor, its promoter is methylated in melanoma \\
\hline & $\operatorname{miR}-197[5,41]$ & represses the tumor suppressor gene FUS1 \\
\hline & $\operatorname{miR}-206[5]$ & inhibits the TGF- $\beta$-mediated up-regulation of HDAC4 \\
\hline & $\operatorname{miR}-370[5]$ & targets TRAF4 \\
\hline & miR-19a [35] & \multirow{3}{*}{ component of the miR-17-92 cluster } \\
\hline & miR-20a [35] & \\
\hline & $\operatorname{miR}-92[35]$ & \\
\hline & $\operatorname{miR}-483[5]$ & cooperates with IGF2; upregulated in various carcinomas \\
\hline & $\operatorname{miR}-485$ [5] & putative down-regulator of Nuclear factor (NF)-YB \\
\hline \multirow{5}{*}{$\begin{array}{l}\text { Nodal marginal zone B-cell } \\
\text { lymphomas }\end{array}$} & $\operatorname{miR}-150[5,42]$ & targets c-Myb; plays a key role in B-cell differentiation \\
\hline & $\operatorname{miR}-221[43]$ & required for angiogenesis; promotes endothelial cell migration and proliferation \\
\hline & $\operatorname{miR}-223[43]$ & suppresses cell proliferation by targeting IGF \\
\hline & let-7 family [5] & \multirow{2}{*}{ tumor suppressor } \\
\hline & let-7f $[43]$ & \\
\hline $\begin{array}{l}\text { Splenic marginal zone } \\
\text { B-cell lymphoma }\end{array}$ & miR-144/451 family [5] & regulates erythroid development and susceptibility to oxidative stress \\
\hline \multirow{3}{*}{$\begin{array}{l}\text { Marginal zone B-cell } \\
\text { lymphoma/MALT }\end{array}$} & miR-200 cluster $[5,44]$ & $\begin{array}{l}\text { inhibits metastasis formation, blocks epithelial-mesenchymal transition (EMT); } \\
\text { maintains the epithelial phenotype through targeting the repressors of E-cadherin }\end{array}$ \\
\hline & $\operatorname{miR}-429[5]$ & targets MYC \\
\hline & $\operatorname{miR}-141[5]$ & targets $\mathrm{p} 38 \alpha$, modulates the oxidative stress response \\
\hline \multirow{10}{*}{ Follicular lymphoma (FCL) } & $\operatorname{miR}-138[5]$ & regulates P53 \\
\hline & $\operatorname{miR}-9, \operatorname{miR}-9^{*}[5,36]$ & NF- $\kappa$ B regulators induced by MYC; target E-cadherin \\
\hline & $\operatorname{miR}-155[36]$ & oncomir, regulates cell proliferation, enhances cell survival \\
\hline & $\operatorname{miR}-210[36$ & targets the apoptosis-inducing factor AIFM3 \\
\hline & $\operatorname{miR}-301[36]$ & mediates proliferation via $\mathrm{NF}-\kappa \mathrm{B}$ \\
\hline & $\operatorname{miR}-143[37]$ & \multirow{2}{*}{ tumor-suppressor Ras activation represses the miR-143/145 cluster } \\
\hline & $\operatorname{miR}-145$ [37] & \\
\hline & $\operatorname{miR}-221[37]$ & required for angiogenesis; promotes endothelial cell migration and proliferation. \\
\hline & let-7b, let7i [37] & let-7 family members, tumor suppressors \\
\hline & $\operatorname{miR}-494$ [43] & regulates PTEN expression \\
\hline
\end{tabular}




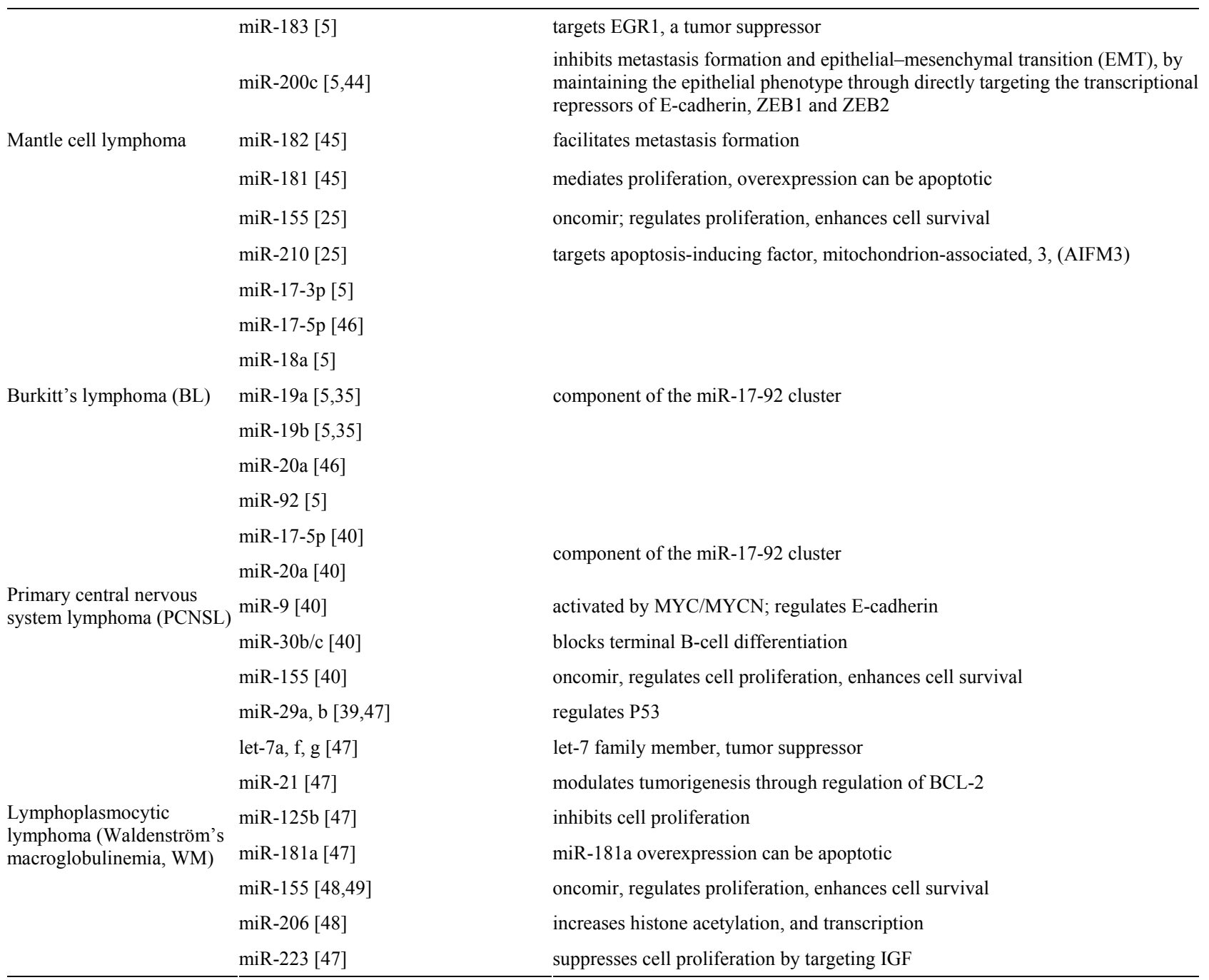

treatment [23]. Gastric marginal zone B-cell lymphoma of MALT type (MALT lymphoma), an indolent disease, may progress to a more aggressive disease, gastric diffuse large B-cell lymphoma (gDLBCL) due to overexpression of the Myc oncoprotein [24]. Myc transcriptionally represses a series of miRNAs including miR-34a, that has antiproliferative properties when overexpressed in DLBCL cells. This effect could be attributed to the suppression of FoxP1, a pioneer transcription factor and miR-34a target. Craig et al. speculated that miR-34a replacement therapy could be beneficial in miR-34a negative hematopoietic malignancies, including gDLBCL [24]. Transcriptional silencing of miR-29 in mantle cell lymphoma is also associated with Myc [25]). In a study performed by Zhao et al., miR-29 levels were associated with prognosis: patients with significantly reduced expression of miR-29 had a short survival compared with those who expressed relatively high levels [26]. It was observed that Myc repressed miR-29 through EZH2, a component of the Polycomb repressor complex that ensures the inheritance of gene expression patterns from cell generation to cell generation, and the histone deacetylase HDAC3, that also marks repressed chromatin domains [25]. Epigenetic drugs inhibiting both EZH2 and HDAC3 could restore miR-29 expression and suppressed lymphoma growth both in vitro and in vivo. These studies suggest that epigenetic therapy might be efficient in the treatment of certain B-cell malignancies. In addition to gDLBCL and mantle cell lymphoma, Burkitt's lymphomas carrying characteristic $c-M y c$ translocations may also fall into this category.

\subsection{Cellular and Viral miRNAs as Possible Therapeutic Targets in Virus-Associated Lymphomas}

The pattern of Epstein-Barr virus (EBV), a human gammaherpesvirus, is associated with a series of malignant tumors, including B-cell lymphomas (reviewed in [27]. 
Table 2. MicroRNAs down-regulated in B-cell lymphomas.

\begin{tabular}{|c|c|c|}
\hline Lymphoma type & miRNA (references) & Comments \\
\hline \multirow{6}{*}{$\begin{array}{l}\text { Diffuse large B-cell } \\
\text { lymphoma (DLBCL) }\end{array}$} & $\operatorname{miR}-145[36]$ & $\begin{array}{l}\text { tumor suppressor in various cancers; Ras activation represses the miR-143/145 } \\
\text { cluster }\end{array}$ \\
\hline & $\operatorname{miR}-150[36,42]$ & regulates c-Myb; and plays a key role in B-cell differentiation \\
\hline & $\operatorname{miR}-139[36]$ & suppresses metastasis and progression of liver carcinoma. \\
\hline & $\operatorname{miR}-149[36]$ & miR-149* induces apoptosis by inhibiting Akt1 and E2F1 \\
\hline & $\operatorname{miR}-320[36]$ & reduces ERK1/2 protein levels \\
\hline & let-7e $[36]$ & tumor suppressor \\
\hline \multirow{16}{*}{$\begin{array}{l}\text { Chronic lymphocytic } \\
\text { leukemia/small lymphocytic } \\
\text { lymphoma (CLL/SLL) }\end{array}$} & let-7 family (a, d, e, f, g) [5] & let-7 family member, tumor suppressor effect \\
\hline & $\operatorname{miR}-100[5]$ & suppresses IGF2 in breast cancer \\
\hline & $\operatorname{miR}-125 \mathrm{a}[5]$ & targets the negative NF- $\kappa \mathrm{B}$ regulator TNFAIP3 \\
\hline & $\operatorname{miR}-143[5]$ & tumor-suppressor; repressed by Ras activation. \\
\hline & $\operatorname{miR}-146 a[5]$ & $\begin{array}{l}\text { targets TRAF6 and IRAK1, the Toll-like and cytokine receptor pathway adaptor } \\
\text { molecules }\end{array}$ \\
\hline & $\operatorname{miR}-15 b[51]$ & \multirow{2}{*}{ miR-15 and miR-16 are direct transcriptional targets of E2F1 } \\
\hline & $\operatorname{miR}-16[51]$ & \\
\hline & $\operatorname{miR}-17-5 p[5]$ & \multirow[t]{2}{*}{ component of the miR-17-92cluster } \\
\hline & $\operatorname{miR}-20 a, b[5]$ & \\
\hline & $\operatorname{miR}-182[5]$ & facilitates metastasis formation \\
\hline & $\operatorname{miR}-223[5]$ & suppresses cell proliferation by targeting IGF \\
\hline & $\operatorname{miR}-34 \mathrm{a}[5]$ & tumor supressor \\
\hline & $\operatorname{miR}-451[5]$ & regulates erythroid development and susceptibility to oxidative stress \\
\hline & $\operatorname{miR}-7[5]$ & inhibits tumor growth and metastasis \\
\hline & $\operatorname{miR}-9, \operatorname{miR}-9^{*}[5]$ & activated by MYC/MYCN, regulates E-cadherin \\
\hline & $\operatorname{miR}-98[5,41]$ & targets the tumor suppressor FUS1 \\
\hline $\begin{array}{l}\text { Nodal marginal zone B-cell } \\
\text { lymphoma }\end{array}$ & $\operatorname{miR}-370[52]$ & down-regulated in gastrointestinal tumors with $14 \mathrm{q}$ loss \\
\hline Splenic marginal zone & $\operatorname{miR}-141[5,44]$ & $\begin{array}{l}\text { the miR-200 family inhibits the initiating step of metastasis, the epithelial } \\
\text { mesenchymal transition (EMT), by maintaining the epithelial phenotype through } \\
\text { directly targeting the transcriptional repressors of E-cadherin, ZEB1 and ZEB2 }\end{array}$ \\
\hline 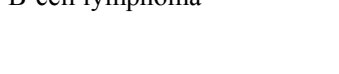 & & $\begin{array}{l}\text { apoptosis-inducing factor, mitochondrion-associated, } 3 \text { (AIFM3) could be a direct } \\
\text { target gene of miR-210 }\end{array}$ \\
\hline $\begin{array}{l}\text { Marginal zone B-cell } \\
\text { lymphoma/MALT }\end{array}$ & $\operatorname{miR}-126^{*}[5,50]$ & diagnostic for acute myeloid leukemia cases with common translocations. \\
\hline \multirow{3}{*}{ Follicular lymphoma (FCL) } & $\operatorname{miR}-320[36]$ & reduces ERK1/2 protein levels and glucose induced ERK1/2 phosphorylation \\
\hline & $\operatorname{miR}-149[36]$ & induces apoptosis by inhibiting Akt1 and E2F1 \\
\hline & $\operatorname{miR}-139[36]$ & $\begin{array}{l}\text { suppresses metastasis and progression of hepatocellular carcinoma by } \\
\text { down-regulating Rho-kinase } 2 \text {. }\end{array}$ \\
\hline \multirow{4}{*}{ Mantle cell lymphoma } & $\operatorname{miR}-126^{*}[45,50]$ & $\begin{array}{l}\text { it's expression distinguishes acute myeloid leukemia cases with common } \\
\text { translocations }\end{array}$ \\
\hline & miR-29a, b, c [25,39] & regulates P53 \\
\hline & $\operatorname{miR}-150[25,42]$ & regulates c-Myb expression; plays a key role in B-cell differentiation \\
\hline & $\operatorname{miR}-15 a, b[25]$ & miR-15 is a direct transcriptional targets of E2F1 cosing proliferation \\
\hline
\end{tabular}




\begin{tabular}{lll} 
Continued & & \\
\hline & let-7 family (a, d, e, f, g) [5] & tumor suppressor \\
& miR-29 family a, b, c [5,39] & $\begin{array}{l}\text { regulates P53 } \\
\text { regulates erythroid development, homeostasis and susceptibility to oxidative stress }\end{array}$ \\
Burkitt's lymphoma (BL) & miR-146a [53] & $\begin{array}{l}\text { down-regulates TRAF6 and IRAK1, the Toll-like and cytokine receptor pathway } \\
\text { adaptor molecules }\end{array}$ \\
& miR-150 [5,42] & regulates c-Myb; plays a key role in B-cell differentiation \\
& miR-155 [53] & oncogenic; regulates cell proliferation, enhances cell survival \\
& miR-145 [40] & tumor-suppressor \\
$\begin{array}{l}\text { Primary central nervous } \\
\text { system lymphoma (PCNSL) }\end{array}$ & miR-214 [40] & targets ATF4 \\
& miR-9 [47-49] & activated by MYC/MYCN; regulates E-cadherin \\
miR-152 [47] & tumor suppressor \\
$\begin{array}{l}\text { Lymphoplasmocytic } \\
\text { lymphoma (Waldenström's } \\
\text { macroglobulinemia, WM) }\end{array}$ & miR-182 [47] & facilitates metastasis formation \\
& miR-15a [48] $[48]$ & tumor suppressor \\
& & tumor suppressor \\
\hline
\end{tabular}

One of the viral oncogenes expressed in nasopharyngeal carcinomas, post-transplant lymphomas, EBV-associated Hodgkin disease and in vitro transformed lymphoblastoid cell lines (LCLs) encodes a transmembrane protein called latent membrane protein 1 (LMP1) that affects the levels of certain cellular microRNAs by activating the NF- $\kappa$ B pathway. Cameron et al. observed that LMP1 induced miR-146a expression, down-regulating the products of a group of interferon-responsive genes [28]. miR-155, implicated in the development of B cell lymphomas, was also upregulated by LMP1 [29]. These virus-induced cellular miRNAs as well as the EBV-encoded miRNAs (reviewed in [30]) are also potential targets of lymphoma therapy.

\section{5. miRNAs as Potential Target Molecules in Radiotherapy and Chemotherapy of Mantle Cell Lymphoma}

Mantle cell lymphoma (MCL), comprising 5\% - 10\% of human B-cell malignancies is considered to be incurable with standard immuno-chemotherapy [31]. For this reason, a novel therapeutic strategy was elaborated, based on the delivery of radioisotopes to the tumor tissue using monoclonal antibodies. Anticipating the development of radioresistant MCL cells, Jiang et al. studied the effect of miRNA-17-92, an oncomir upregulated in various neoplasms, on radiosensitivity of a human MCL cell line in vitro [32]. They observed that over-expression of miRNA-17-92 increased the survival of irradiated cells by indirectly up-regulating expression of the AKT protein kinase [32]. Thus, suppressing miRNA-17-92 may improve, in principle, the efficiency of MCL radiotherapy. It is worthy to note that another miRNA, miR-155, could be induced by hypoxia and protected lung cancer cells from radiation [33]. Treatment with anti-miR-155 mole- cules, however, radiosensitized the cells in vitro. Overexpression of miRNA-17-92 cluster inhibited chemotherapy-induced apoptosis in MCL cell lines in vitro [34]. miR-17-92 targeted a protein phosphatase involved in the negative regulation of the PI3K/AKT pathway, resulting in AKT activation. Rao et al. suggested that targeting the miRNA-17-92 cluster could be a plausible approach in MCL chemotherapy [34].

\section{Conclusion}

Recent developments in the synthesis of sophisticated, chemically modified antisense oligonucleotides targeting oncomirs and the use of anti-miR nanoparticle complexes made possible the development of new therapeutic approaches that may complement current protocols for Bcell lymphoma therapy. Anti-cytokine therapy aiming at the removal of cytokines that activate the biogenesis of key oncomirs might also be considered in case of well defined patient groups. Suppression of oncomir expression may successfully complement, on the long run, radiotherapy and chemotherapy of certain B-cell lymphoma types. In addition, switching on silenced tumor suppressor miRNAs by epigenetic drugs also appears to be a promising strategy in B-cell lymphoma treatment.

\section{Acknowledgements}

We are grateful to Ms. Zsófia Papp for her help in the preparation of the manuscript.

\section{REFERENCES}

[1] D. Sayed and M. Abdellatif, "MicroRNAs in Development and Disease," Physiological Reviews, Vol. 91, No. 3, 2011, pp. 827-887. doi:10.1152/physrev.00006.2010

[2] L. Ma and A. Weinberg, "MicroRNAs in Malignant Pro- 
gression," Cell Cycle, Vol. 7, No. 5, 2008, pp. 570-572. doi:10.4161/cc.7.5.5547

[3] S. A. Melo and M. Esteller, "Dysregulation of microRNAs in Cancer: Playing with Fire," FEBS Letters, Vol. 585, No. 13, 2011, pp. 2087-2099. doi:10.1016/j.febslet.2010.08.009

[4] M. Fabbri and C. M. Croce, "Role of microRNAs in Lymphoid Biology and Disease," Current Opinion in Hematology, Vol. 18, No. 4, 2011, pp. 266-272. doi:10.1097/MOH.0b013e3283476012

[5] L. Di Lisio, M. Sánchez-Beato, G. Gómez-López, M. E. Rodríguez, S. Montes-Moreno, M. Mollejo, J. Menárguez, M. A. Martínez, F. J. Alves, D. G. Pisano, M. A. Piris and N. Martínez, "MicroRNA Signatures in B-Cell Lymphomas," Blood Cancer Journal, Vol. 2, No. 2, 2012, Article ID: e57. doi:10.1038/bcj.2012.1

[6] P. S. Eis, W. Tam, L. Sun, A. Chadbun, Z. Li, M. F. Gomez, E. Lund and J. E. Dahlberg, "Accumulation of miR155 and BIC RNA in Human B Cell Lymphomas," Proceedings of the National Academy of Sciences, USA, Vol. 102 , No. 10, 2005, pp. 3627-3632. doi:10.1073/pnas.0500613102

[7] J. Kluiver, S. Poppema, D. de Jong, T. Blokzijl, G. Harms, S. Jacobs, B. J. Kroessen and A. van den Berg, "BIC and miR-155 Are Highly Expressed in Hodgkin, Primary Mediastinal and Diffuse Large B Cell Lymphomas," Journal of Pathology, Vol. 207, No. 2, 2005, pp. 243-249. doi:10.1002/path. 1825

[8] S. Costinean, N. Zanesi, Y. Pekarsky, E. Tili, S. Volinia, N. Heerema and C. M. Croce, "Pre-B Cell Proliferation and Lymphoblastic Leukemia/High-Grade Lymphoma in $\mathrm{E}(\mathrm{mu})-\mathrm{miR} 155$ Transgenic Mice," Proceedings of the $\mathrm{Na}$ tional Academy of Sciences, USA, Vol. 103, No. 18, 2006, pp. 7024-7029. doi:10.1073/pnas.0602266103

[9] S. Costinean, S. K. Sandhu, I. M. Pedersen, E. Tili, R. Trotta, D. Perrotti, D. Ciarlariello, P. Neviani, J. Harb, L. R. Kauffmann, A. Shidham and C. M. Croce, "Src Homology Domain-Containing Inositol-5-Phosphatase and CCAAT Enhancer-Binding Protein $\beta$ Are Targeted by miR-155 in B Cells of E $\mu$-MIR-155 Transgenic Mice," Blood, Vol. 114, No. 7, 2009, pp. 1374-1382. doi:10.1182/blood-2009-05-220814

[10] C. L. Li, H. Nie, M. Wang, L. P. Su, J. F. Li, Y. Y. Yu, M. Yan, Q. L. Qu, Z. G. Zhu and B. Y. Liu, "microRNA-155 Is Downregulated in Gastric Cancer Cells and Involved in Cell Metastasis," Oncology Report, Vo. 27, No. 6, 2012, pp. 1960-1966. doi:10.3892/or.2012.1719

[11] I. A. Babar, C. J. Cheng, C. J. Booth, X. Liang, J. B. Weidhaas, W. M. Saltzman and F. J. Slack, "Nanoparticle-based Therapy in an in Vivo microRNA-155 (miR155)-Dependent Mouse Model of Lymphoma," Proceedings of the National Academy of Sciences, USA, Vol. 109, No. 26, 2012, pp. E1695-E1704. doi:10.1073/pnas.1201516109

[12] A. G. Torres, M. M. Fabiani, E. Vigorito and M. J. Gait, "MicroRNA Fate upon Targeting with Anti-miRNA Oligonucleotides as Revealed by an Improved NorthernBlot-Based Method for miRNA Detection," RNA-A Publication of RNA Society, Vol. 17, No. 5, 2011, pp. 933-
943. doi:10.1261/rna.2533811

[13] O. Snove and J. J. Rossi, "Toxicity in Mice Expressing Short Hairpin RNAs Gives New Insight into RNAi," Genome Biology, Vol. 7, No. 8, 2006, Article ID: 231. doi:10.1186/gb-2006-7-8-231

[14] D. Peer and M. Shimaoka, "Systemic siRNA Delivery to Leukocyte-Implicated Diseases," Cell Cycle, Vol. 8, No. 6, 2009, pp. 853-859. doi:10.4161/cc.8.6.7936

[15] M. M. Fabani and M. J. Gait, "miR-122 Targeting with LNA/2'-O-Methyl Oligonucleotide Mixmers, Peptide Nucleic Acids (PNA), and PNA-Peptide Conjugates," $R N A$ A Publication of RNA Society, Vol. 14, No. 2, 2008, pp. 336-346. doi:10.1261/rna.844108

[16] M. M. Fabani, C. Abreu-Goodger, D. Williams, P. A. Lyons, A. G. Torres, K. G. C. Smith, A. J. Enright, M. J. Gait and E. Vigorito, "Efficient Inhibition of miR-155 Function in Vivo by Peptide Nucleic Acids," Nucleic Acids Research, Vol. 38, No. 13, 2010, pp. 4466-4475. doi:10.1093/nar/gkq160

[17] J. Krützfeldt, S. Kuwajima, R. Braich, K. G. Rajeev, J. Pena, T. Tuschl, M. Manoharan and M. Stoffel, "Specificity, Duplex Degradation and Subcellular Localization of Antagomirs," Nucleic Acids Research, Vol. 35, No. 9, 2007, pp. 2885-2892. doi:10.1093/nar/gkm024

[18] Y. Zhang, A. M. Roccaro, C. Rombaoa, L. Flores, S. Obad, S. M. Fernandes, A. Sacco, Y. Liu, H. Ngo, P. Quang, A. K. Azab, F. Azab, P. Maiso, M. Reagan, J. R. Brown, T. H. Thai, S. Kauppinen and I. M. Ghobrial, "LNA-Mediated Anti-miR-155-Silencing in Low Grade B-Cell Lymphomas," Blood, Vol. 120, No. 8, 2012, pp. 1678-1686. doi:10.1182/blood-2012-02-410647

[19] V. Prabhu, S. Uzzaman, V. M. B. Grace and C. Guruvayoorappan, "Nanoparticles in Drug Delivery and Cancer Therapy: The Giant Rats Tail," Journal of Cancer Therapy, Vol. 2, 2011, pp. 325-334. doi:10.4236/jet.2011.23045

[20] J. Su, H. Baigude, J. McCarroll and T. M. Rana, "Silencing microRNA by Interfering Nanoparticles in Mice," Nucleic Acids Research, Vol. 39, No. 6, 2011, Article ID: e38. doi:10.1093/nar/gkq1307

[21] T. H. Thai, D. P. Calado, K. M. Ansel, C. Xiao, Y. Xue, A. Murphy, D. Frendewey, D. Valenzuela, J. L. Kutok, M. Schmidt-Supprian, N. Rajewsky, G. Yancopoulos, A. Rao and K. Rajewsky, "Regulation of the Germinal Center Response by microRNA-155," Science, Vol. 316, No. 5824, 2007, pp. 604-608. doi:10.1126/science.1141229

[22] I. Pedersen, D. Otero, A. V. Miletic, C. Hother, E. Ralfkiaer, R. C. Rickert, K. Gronbaek and M. David, "OncomiR-155 Targets SHIP1 to Promote TNF $\alpha$-Dependent Growth of B Cell Lymphomas," EMBO Molecular Medicine, Vol. 1, No. 5, 2009, pp. 288-295. doi:10.1002/emmm.200900028

[23] Y. A. Mian and N. J. Zeleznik-Le, "MicroRNAs in Leukemias: Emerging Diagnostic Tools and Therapeutic Targets," Current Drug Targets, Vol. 11, No. 7, 2010, pp. 801-811. doi:10.2174/138945010791320872

[24] V. J. Craig, S. B. Cogliatti, J. Imig, C. Renner, S. Neuenschwander, H. Rehrauer, R. Schlapbach, S. Dimhofer, A. 
Tzankov and A. Müller, "Myc-Mediated Repression of microRNA-34a Promotes High-Grade Transformation of B Cell Lymphoma by Dysregulation of FoxP1," Blood, Vol. 117, No. 23, 2011, pp. 6227-6236.

[25] X. Zhang, X. Zhao, W. Fiskus, J. Lin, T. Lwin, R. Rao, Y. Zhang, J. C. Chan, K. Fu, V. E. Marquez, S. Chen-Kiang, L. C. Moscinski, E. Seto, W. S. Dalton, K. L. Wright, E. Sotomayor, K. Bhalla and J. Tao, "Coordinated Silencing of MYC-Mediated miR-29 by HDAC3 and EZH2 as a Therapeutic Target of Histone Modification in Aggressive B Cell Lymphoma," Cancer Cell, Vol. 22, No. 4, 2012, pp. 506-523. doi:10.1016/i.ccr.2012.09.003

[26] J. J. Zhao, J. Lin, T. Lwin, H. Yang, J. Guo, W. Kong, S. Dessureault, L. C. Moscinski, D. Rezania, W. S. Dalton, E. Sotomayor, J. Tao and J. Q. Cheng, "microRNA Expression Profile and Identification of miR-29 as a Prognostic Marker and Pathogenic Factor by Targeting CDK6 in Mantle Cell Lymphoma," Blood, Vol. 115, No. 13, 2010, pp. 2630-2639. doi:10.1182/blood-2009-09-243147

[27] M. Takacs, F. Banati, A. Koroknai, J. Segesdi, D. Salamon, H. Wolf, H. H. Niller and J. Minarovits, "Epigenetic Regulation of Latent Epstein-Barr Virus Promoters," Biochimica et Biophysica Acta, Vol. 1799, No. 3-4, 2010, pp. 228-235. doi:10.1016/j.bbagrm.2009.10.005

[28] J. E. Cameron, Q. Yin, C. Fewell, M. Lacey, J. McBride, X. Wang, Z. Lin, B. C. Schaefer and E. K. Flemington, "Epstein-Barr Virus Latent Membrane Protein 1 Induces Cellular microRNA miR-146A, a Modulator of Lymphocyte Signaling Pathways," Journal of Virology, Vol. 82, No. 4, 2008, pp. 1946-1958. doi:10.1128/JVI.02136-07

[29] F. Lu, A. Weidmer, C. G. Liu, S. Volnia, C. M. Croce and P. M. Lieberman, "Epstein-Barr Virus-Induced miR-155 Attenuates NF-kappaB Signaling and Stabilizes Latent Virus Persistence," Journal of Virology, Vol. 82, No. 21, 2008, pp. 10436-10443. doi:10.1128/JVI.00752-08

[30] B. R. Cullen, "Viruses and microRNAs: RISCy Interactions with Serious Consequences," Genes \& Development, Vol. 25, No. 18, 2011, pp. 1881-1894.

[31] A. P. Skarbnik and M. R. Smith, "Radioimmunotherapy in Mantle Cell Lymphoma," Best Practice \& Research Clinical Haematology, Vol. 25, No. 2, 2012, pp. 201-210. doi:10.1016/j.beha.2012.04.004

[32] P. Jiang, E. Y. Rao, N. Meng, Y. Zhao and J. J. Wang, "MicroRNA-17-92 Significantly Enhances Radioresistance in Human Mantle Cell Lymphoma Cells," Radiation Oncology, Vol. 5, 2010, Article ID: 100. doi:10.1186/1748-717X-5-100

[33] I. A. Babar, J. Czochor, A. Steinmetz, J. B. Weidhaas, P. M. Glazer and F. J. Slack, "Inhibition of Hypoxia-Induced miR-155 Radiosensitizes Hypoxic Lung Cancer Cells," Cancer Biology \& Therapy, Vol. 12, No. 10, 2012, pp. 908-914. doi:10.4161/cbt.12.10.17681

[34] E. Rao, C. Jiang, M. Ji, X. Huang, J. Ibgal, G. Lenz, G. Wright, L. M. Staudt, Y. Zhao, T. W. McKeithan, W. C. Chan and K. Fu, "The miRNA-17 92 Cluster Mediates Chemoresistance and Enhances Tumor Growth in Mantle Cell Lymphoma via PI3K/AKT Pathway Activation," Leukemia, Vol. 26, No. 5, 2012, pp. 1064-1072. doi:10.1038/leu.2011.305
[35] J. H. Gibcus, L. P. Tan, G. Harms, R. N. Schakel, D. de Jong, T. Blokzijl, P. Möller, S. Poppema, B. J. Kroesen and A. van den Berg, "Hodgkin Lymphoma Cell Lines Are Characterized by a Specific miRNA Expression Profile," Neoplasia, Vol. 11, No. 2, 2009, pp. 167-176.

[36] A. Roehle, K. P. Hoefig, D. Repsilber, C. Thorns, M. Ziepert, K. O. Wesche, M. Thiere, M. Loeffler, W. Klapper, M. Pfreundschuh, A. Matolcsy, H. W. Bernd, L. Reiniger, H. Merz and A. C. Feller, "MicroRNA Signatures Characterize Diffuse Large B-Cell Lymphomas and Follicular Lymphomas," British Journal of Haematology, Vol. 142, No. 5, 2008, pp. 732-744. doi:10.1111/j.1365-2141.2008.07237.x

[37] C. H. Lawrie, J. Chi, S. Taylor, D. Tramonti, E. Ballabio, S. Palazzo, N. J. Saunders, F. Pezzella, J. Boultwood, J. S. Wainscoat and C. S. Hatton, "Expression of microRNAs in Diffuse Large B Cell Lymphoma Is Associated with Immunophenotype, Survival and Transformation from Follicular Lymphoma," Journal of Cellular and Molecular Medicine, Vol. 13, No. 7, 2009, pp. 1248-1260. doi:10.1111/j.1582-4934.2008.00628.x

[38] D. Rai, S. Karanti, I. Jung, P. L. Dahia and R. C. Aguiar, "Coordinated Expression of microRNA-155 and Predicted Target Genes in Diffuse Large B-Cell Lymphoma," Cancer Genetics and Cytogenetics, Vol. 181, No. 1, 2008, pp. 8-15. doi:10.1016/j.cancergencyto.2007.10.008

[39] S. Y. Park, J. H. Lee, M. Ha, J. W. Nam and V. N. Kim, "miR-29 miRNAs Activate p53 by Targeting p85 Alpha and CDC42," Nature Structural and Molecular Biology, Vol. 16, No. 1, 2009, pp. 23-29. doi:10.1038/nsmb.1533

[40] L. Fischer, M. Hummel, A. Korfel, D. Lenze, K. Joehrens and E. Thiel, "Differential micro-RNA Expression in Primary CNS and Nodal Diffuse Large B-Cell Lymphomas," Neuro-Oncology, Vol. 13, No. 10, 2011, pp. 1090 1098. doi:10.1093/neuonc/nor107

[41] L. Du, J. J. Schageman, M. C. Subauste, B. Saber, S. M. Hammond and L. Prudkin, "miR-93, miR-98, and miR197 Regulate Expression of Tumor Suppressor Gene FUS1," Molecular Cancer Research, Vol. 7, No. 8, 2009, pp. 1234-1243. doi:10.1158/1541-7786.MCR-08-0507

[42] C. Xiao, D. P. Calado, G. Galler, T. H. Thai, H. C. Patterson, J. Wang, N. Rajewsky, T. P. Bender and K. Rajewsky, "MiR-150 Controls B Cell Differentiation by Targeting the Transcription Factor c-Myb," Cell, Vol. 131, No. 1, 2007, pp. 146-159. doi:10.1016/j.cell.2007.07.021

[43] A. J. Arribas, Y. Campos-Martín, C. Gómez-Abad, P. Algara, M. Sánchez-Beato, M. S. Rodriguez-Pinilla, S. Montes-Moreno, N. Martinez, J. Alves-Ferreira, M. A. Piris and M. Mollejo, "Nodal Marginal Zone Lymphoma: Gene Expression and miRNA Profiling Identify Diagnostic Markers and Potential Therapeutic Targets," Blood, Vol. 119, No. 3, 2012, pp. e9-e21. doi:10.1182/blood-2011-02-339556

[44] S. M. Park, A. B. Gaur, E. Lengyel and M. E. Peter, "The miR-200 Family Determines the Epithelial Phenotype of Cancer Cells by Targeting the E-Cadherin Repressors ZEB1 and ZEB2," Genes Development, Vol. 22, No. 7, 2008, pp. 894-907. doi:10.1101/gad.1640608 
[45] L. Di Lisio, G. Gomez-Lopez, M. Sanchez-Beato, C. Gomez-Abad, M. E. Rodriguez, R. Villuendas, B. I. Ferreira, A. Carro, D. Rico, M. Mollejo, M. A. Martínez, J. Menárguez, A. Díaz-Alderete, J. Gil, J. C. Cigudosa, D. G. Pisano, M. A. Piris and N. Martínez, "Mantle Cell Lymphoma: Transcriptional Regulation by microRNAs," Leukemia, Vol. 24, No. 7, 2010, pp. 1335-1342. doi:10.1038/leu.2010.91

[46] A. Onnis, G. de Falco, G. Antonicelli, M. Onorati, C. Bellan, O. Sherman, S. Sayed and L. Leoncini, "Alteration of microRNAs Regulated by c-Myc in Burkitt Lymphoma," PLoS ONE, Vol. 5, No. 9, 2010, p. e12960. doi:10.1371/journal.pone.0012960

[47] L. S. Hodge, S. F. Elsawa, D. M. Grote, T. L. PriceTroska, Y. W. Asmann, R. Fonseca, M. A. Gertz, T. E. Witzig, A. J. Novak and S. M. Ansell, "MicroRNA Expression in Tumor Cells from Waldenstrom's Macroglobulinemia Reflects Both Their Normal and Malignant Cell Counterparts," Blood Cancer Journal, Vol. 1, No. 6, 2011, Article ID: e24. doi:10.1038/bcj.2011.25

[48] E. Braggio, C. Philipsborn, A. Novak, L. Hodge, S. Ansell and R. Fonseca, "Molecular Pathogenesis of Waldenstrom's Macroglobulinemia," Haematologica, Vol. 97, No. 9, 2012, pp. 1281-1290. doi:10.3324/haematol.2012.068478

[49] A. M. Roccaro, A. Sacco, C. Chen, J. Runnels, X. Leleu, F. Azab, A. K. Azab, X. Jia, H. T. Ngo, M. R. Melhem, N. Burwick, L. Varticovski, C. D. Novina, B. J. Rollins, K. C. Anderson and I. M. Ghobrial, "MicroRNA Expression in the Biology, Prognosis, and Therapy of Waldenström Macroglobulinemia," Blood, Vol. 113, No. 18, 2009, pp. 4391-4402. doi:10.1182/blood-2008-09-178228

[50] Z. Li, J. Lu, M. Sun, S. Mi, H. Zhang, R. T. Luo, P. Chen,
Y. Wang, M. Yan, Z. Qian, M. B. Neilly, J. Jin, Y. Zhang, S. K. Bohlander, D. E. Zhang, R. A. Larson, M. M. Le Beau, M. J. Thirman, T. R. Golub, J. D. Rowley and J. Chen, "Distinct microRNA Expression Profiles in Acute Myeloid Leukemia with Common Translocations," Proceedings of the National Academy of Sciences of the United States of America, Vol. 105, No. 40, 2008, pp. 15535-15540. doi:10.1073/pnas.0808266105

[51] G. A. Calin, C. D. Dumitru, M. Shimizu, R. Bichi, S. Zupo, E. Noch, H. Aldler, S. Rattan, M. Keating K. Rai, L. Rassenti, T. Kipps, M. Negrini, F. Bullrich and C. M. Croce, "Frequent Deletions and Down-Regulation of Micro-RNA Genes miR15 and miR16 at 13q14 in Chronic Lymphocytic Leukemia," Proceedings of the National Academy of Sciences of the United States of America, Vol. 99, No. 24, 2002, pp. 15524-15529. doi:10.1073/pnas.242606799

[52] F. Haller, A. Von Heydebreck, J. D. Zhang, B. Gunawan, C. Langer, G. Ramadori, S. Wiemann and O. Sahin, "Localization- and Mutation-Dependent microRNA (miRNA) Expression Signatures in Gastrointestinal Stromal Tumours (GISTs), with a Cluster of Co-Expressed miRNAs Located at 14q32.31," Journal of Pathology and Bacteriology, Vol. 220, No. 1, 2010, pp. 71-86. doi:10.1002/path.2610

[53] J. L. Robertus, J. Kluiver, C. Weggemans, G. Harms, R. M. Reijmers, Y. Swart, K. Kok, S. Rosati, E. Schuuring, G. van Imhoff, S. T. Pals, P. Kluin and A. van den Berg, "MiRNA Profiling in B Non-Hodgkin Lymphoma: A MYC-Related miRNA Profile Characterizes Burkitt Lymphoma," British Journal of Haematology, Vol. 149, No. 6, 2010, pp. 896-899.

doi:10.1111/j.1365-2141.2010.08111.x 